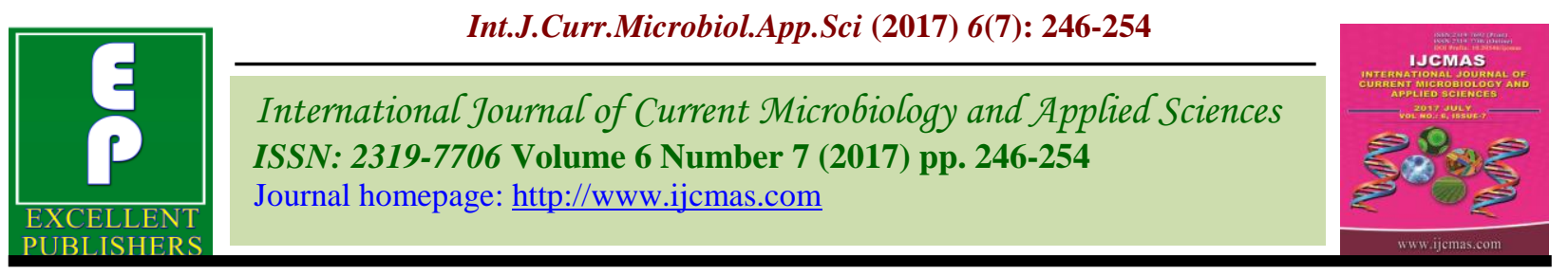

Original Research Article https://doi.org/10.20546/ijcmas.2017.607.029

\title{
Using Augmented Design for Evaluation of Common Bean (Phaseolus vulgaris L.) Germplasm
}

\author{
Iram Saba, Parvaze A. Sofi*, N.A. Zeerak, R.R. Mir and Musharib Gull \\ Division of Plant Breeding and Genetics, SKUAST-K, Wadura, Sopore, 193201, J \& K, India \\ *Corresponding author
}

\section{A B S T R A C T}

Genetic resources enable plant breeders to create novel plant gene combinations and select crop varieties more suited to the needs of diverse agricultural system. In the present study, 200 test entries along with 3 checks were evaluated in an augmented block design for yield and yield component traits. The mean values of days to flowering, days to maturity, plant height $(\mathrm{cm})$, number of pods per plant, pod length $(\mathrm{cm})$, seeds per pod, 100 seed weight $(\mathrm{g})$ and seed yield per plant $(\mathrm{g})$ were $44.040 \pm 0.039,81.698 \pm 0.593,102.503 \pm 5.071,15.152$

Keywords

Augmented design, Common bean, Yield, Principal Component analysis.

\section{Article Info}

\section{Accepted:}

04 June 2017

Available Online:

10 July 2017 $\pm 0.445,12.465 \pm 0.149,4.327 \pm 0.041,36.416 \pm 0.667$ and $19.173 \pm 0.532$, respectively. The Analysis of variance revealed significant mean sum of squares for all traits for different sources of variation. The Block effect (unadjusted) and the treatment effects (adjusted as well as unadjusted) were significant for all the traits. Similarly the effects due to checks and varieties were significant. However, the adjusted block effects were nonsignificant for all traits except pods per plant indicating homogeneity of evaluation blocks. Similarly, the mean square due to checks v/s varieties was significant for all the traits except days to maturity, indicating thereby that the test entries were significantly different from checks except for days to maturity. The number of genotypes that surpassed the best check was 19 (days to flowering), 37 (days to maturity), 88 (plant height), 2 (number of pods per plant), 1 (pod length), 5 (seeds per pod), 41 (100 seed weight) and 10 (seed yield per plant). Shalimar French Bean-1 was the best check for all traits except plant height (Arka Anoop) and 100-seed weight (Shalimar Rajmash-1). Only three principal components had Eigen values above unity and as such were considered. The latent roots ranged from 2.375 for first PC to 0.121 for the eighth PC. The first component explained $29.7 \%$ of variation followed by PC $2(23.9 \%)$ and PC $3(15.3 \%)$. Seed yield per plant was significantly and positively correlated with the number of pods per plant and 100 -seed weight while as number of seeds per pod was positively correlated with pod length. The only significant negative correlation was between pod length and plant height. Similarly, positive but non-significant correlations were recorded between seed yield per plant and number of seeds per pod, pod length, DF as well as plant height.

\section{Introduction}

India is the largest producer and consumer of pulses in the world yet it is the largest importer of pulses (Nadrajan and Chaturvedi, 2010). Analysis of factors responsible for low production and productivity levels indicate a multitude of constraints for the dismal scenario that are biological, geographical, agronomic, institutional and socio-economic in nature. High yielding seeds of pulses have not been made available and many of them have been susceptible to pests, diseases and weather fluctuations. The possibility of 
improving yield per se through genetic manipulations has been showing encouraging results in recent years. Common bean is one of the most important summer season pulse crops of Jammu and Kashmir state especially under marginal low input farming systems where the crop is usually grown as a rainfed crop and invariably intercropped with maize. Due to a host of production constraints and complex physiology of beans, the yields are very low and the crop is increasingly becoming uncompetitive despite it being a valuable crop in terms of food and nutritional security potential of this crop.

Despite organised research, the yields of currently available cultivars have not been able to make any dent in the farmer's field and yields continue to be disappointingly low. Therefore it is essential to undertake breeding efforts for developing high yielding varieties that could help increase yields on the farmer's fields. This requires systematic utilisation of available genetic diversity and understanding of nature and extent of variation for yield and its component traits.

The major farming systems having common bean as a component crop are characterized by growing of local landraces that are invariably low yielding, more often disappointingly low, but possess specific adaptation traits that confer niche value. However, the current yield levels in crops, especially pulses, need to be enhanced in order to stay competitive. Genetic resources enable plant breeders to create novel plant gene combinations and select crop varieties more suited to the needs of diverse agricultural system. Plant diversity is an important phenomenon on which further progress in crop improvement relies. The germplasm collections are formed with the objective of conserving the variability of the crop species in order to select the most suitable lines for breeding, both for hybridization and selection of lines from such populations. Ample germplasm resources are available in form of farmers' adapted landraces, collections in national and international gene banks which can be used for identification and development of high yielding bean cultivars. Singh (2001) has stated that very little variability available in different gene pools of common bean has been utilized for crop improvement. Similarly Rana et al., (2015) has made extensive evaluations of Indian gene bank repositories of common bean and concluded that that the variability can be used for developing desirable genotypes based on trait combinations that enhance yield as well as resilience to diseases.

The major bottleneck with using grain yield per se as selection criteria from crop improvement in terms of yields is difficult due to the complexity of its nature as well as low heritability and therefore the realised gains for yield have not been very encouraging by direct selection for yield.

Therefore, there has been greater emphasis across all breeding programmes to study the nature of relationship and trait associations between yield and other traits which are relatively less complex and have comparatively better heritability for use as indirect selection criteria for seeking improvement in yield. The phenotypic correlation among traits reflects the observed relationship between traits arising out of both genetic and environmental factors; while as the genotypic correlations arise from linkage and pleiotropy. The knowledge of trait associations in common bean breeding material is essential for a variety of reasons: it enables us to perceive the diversity of breeding material and identify the trait through which a bean plant is able to grow successfully in a given ecological condition with optimum productivity and to avoid characters that have little or no breeding value in combination with PCA; it enables us to 
narrow down to a very few traits that not only account for large amount of variation but have a breeding value correlated with seed yield.

Augmented designs consist of two kinds of treatments, the checks or the standard treatments and new or augmented treatments (Federer, 1956). The design presumes checks as fixed effects whereas the new entries as random effects. The new entries are usually not replicated owing to large number of entries initially in a breeding programme especially when dealing with large germplasm sets. However, the checks are replicated to act as points of reference. Both the checks and new entries are randomly distributed among the blocks.

Federer (2001) have provided for statistical analyses of such designs wherein the random effects nature of new entries are used to account for various sources of variation. Augmented block design (ABD) accommodates both replicated as well as unreplicated entries and is highly useful in early testing of a huge number of test entries/accessions when the replication is not practically possible, amount of seed is very limited as well as in case of unequal plot sizes.

It saves time and money without compromising on the precision of critical comparisons among treatments. However, a major bottleneck in ABD is that loss of an unreplicated treatment means loss of entire information about that treatment. The augmented design also provides estimates of standard errors of four different comparisons to compute least significant increase. However, the most useful comparison is the difference between adjusted means of test entries and a check mean designated as Least Significant Increase (LSI). The present study was undertaken to analyse the pattern of variation for yield and its component traits in a core set of germplasm accessions representing diverse growth habits as well as pod and seed characteristics.

\section{Materials and Methods}

\section{Location}

The present study was undertaken in Kharif 2014 in the research farm of Faculty of Agriculture, SKUAST-K at Wadura $\left(34^{\circ} 17^{\prime}\right.$ North and $74^{\circ} 33 \mathrm{E}$ at altitude of $1594 \mathrm{~m}$ amsl).

\section{Plant material}

The material used in present study comprised of 203 genotypes including 200 test germplasm accessions (comprising local landraces a well as accessions procured from national and international gene banks) and three checks namely Shalimar Rajmash-1, Shalimar French Bean-1 and Arka Anoop. Shalimar Rajmash-1 and Shalimar French Bean-1 are varieties released by SKUASTKashmir and Arka Anoop is a variety released by IIHR, Bangalore. The material is a part of the common bean collection maintained in Phaseolus Gene Bank at Regional Research Station of SKUAST-K and comprised diverse market classes, growth habits and maturity ranges.

\section{Field design}

The material was evaluated in augmented block design (Federrer, 1956). The design consisted of 10 blocks containing 23 genotypes in each with 20 test entries and three check entries. Each genotype was represented by a plot size of $2 \times 2$ meter dimensions with 5 lines. The plants were space planted for optimal expression of traits. Data was collected from ten randomly selected competitive plants on various morphological, maturity, yield and yield contributing traits. In each block the checks were allotted randomly. 


\section{Statistical analysis}

The analysis of variance was done using SPAD (Statistical Package for Augmented Design) software developed by IASRI, New Delhi. We considered eight quantitative traits related to seed yield namely days to flowering, days to maturity, plant height, number of pods/plant, pod length, seeds/pod, 100 -seed weight and seed yield/plant. The factor analysis was based on Pearson correlation matrix and Euclidean distances. Latent roots or Eigen values for all principal components were shown. Principal component analysis was done using Analyseit software (Analyse-it, UK).

\section{Results and Discussion}

\section{Analysis of augmented design}

Augmented block design (Federrer, 1956) is a method of choice to undertake initial evaluation of a large set of germplasm accessions to select genotypes suitable for different aspects of crop breeding. This is all the more important in cases where initial seed is limited in quantity to undertake replicated experiments as well as our failure to ensure comparably homogenous experimental units which is a basic requirement of standard field designs. The design makes use of a procedure wherein a large number of test entries to be evaluated are evaluated along with standard checks, with the checks being replicated randomly in all blocks. The data from checks is used to adjust mean values of test entries to make them comparable and also provide an estimate of experimental error.

In the present study, 200 test entries along with 3 checks were evaluated in an augmented block design for yield and yield component traits. The mean values (Table 1) of days to flowering, days to maturity, plant height $(\mathrm{cm})$, number of pods per plant, pod length $(\mathrm{cm})$, seeds per pod, 100 seed weight (g) and seed yield per plant $(\mathrm{g})$ were $44.040 \pm$ $0.039,81.698 \pm 0.593,102.503 \pm 5.071$, $15.152 \pm 0.445,12.465 \pm 0.149,4.327 \pm$ $0.041,36.416 \pm 0.667$ and $19.173 \pm 0.532$, respectively. The range for these traits was 30 - 70, 46 - 111, 32.330 - 328.870, 4.667 $40.120,8.040-18.400,2.600-6.230,15.590$ - 66.750 and 5.670 - 54.430, respectively. The highest value of co-efficient of variation (C.V) was found in case of seed yield per plant $(23.309 \%)$ followed by number of pods per plant $(15.941 \%)$ and pod length $(9.291 \%)$ while as days to flowering (3.710\%) and 100seed weight $(3.658 \%)$ had lower C.V values. Figure 1 shows the graphical representation of pattern of variation into different classes for eight quantitative traits. Rana et al., (2015) evaluated 4274 germplasm accession of common bean from 58 countries and observed substantial variability for the 22 traits studied.

Table.1 Descriptive statistics of maturity and yield parameters in 203 genotypes of common bean

\begin{tabular}{|l|c|c|c|}
\hline Trait & Mean \pm SD & Range & CV (\%) \\
\hline Days to flowering & $44.040 \pm 0.039$ & $30-70$ & 3.710 \\
\hline Days to maturity & $81.698 \pm 0.593$ & $46-111$ & 4.373 \\
\hline Plant height $(\mathrm{cm})$ & $102.503 \pm 5.071$ & $32.330-328.870$ & 4.808 \\
\hline Pods per plant & $15.152 \pm 0.445$ & $4.667-40.120$ & 15.941 \\
\hline Pod length $(\mathrm{cm})$ & $12.465 \pm 0.149$ & $8.040-18.400$ & 9.291 \\
\hline Seeds per pod & $4.327 \pm 0.041$ & $2.600-6.230$ & 7.927 \\
\hline 100 seed weight $(\mathrm{g})$ & $36.416 \pm 0.667$ & $15.590-66.750$ & 3.658 \\
\hline Seed yield per plant $(\mathrm{g})$ & $19.173 \pm 0.532$ & $5.670-54.430$ & 23.309 \\
\hline
\end{tabular}


Table.2 Analysis of variance of augmented block design for eight quantitative traits in 203 genotypes of common bean

\begin{tabular}{|c|c|c|c|c|c|c|c|c|c|}
\hline Source of variation & df & DF & DM & $\mathbf{P H}$ & $\mathbf{P} / \mathbf{P}$ & $\mathbf{P L}$ & SPP & 100SW & SYPP \\
\hline $\begin{array}{l}\text { Blocks (ignoring } \\
\text { treatments) }\end{array}$ & 9 & $130.946 * *$ & $312.444 * *$ & $9776.771 * *$ & $57.656^{* *}$ & $8.266 * *$ & $0.335 * *$ & $205.758 * *$ & $143.201 * *$ \\
\hline $\begin{array}{l}\text { Treatments } \\
\text { (eliminating blocks) }\end{array}$ & 202 & $13.345^{* *}$ & $76.045^{* *}$ & $6267.615^{* *}$ & $48.547 * *$ & $5.363 * *$ & $0.407 * *$ & $106.725^{* *}$ & $65.71 * *$ \\
\hline Checks & 2 & $46.633 * *$ & $22.443 * *$ & $423.789 * *$ & $930.823 * *$ & $13.191 * *$ & $1.513 * *$ & $593.993 * *$ & $143.92 * *$ \\
\hline $\begin{array}{l}\text { Blocks (eliminating } \\
\text { checks and varieties }\end{array}$ & 9 & 4.225 & 5.144 & 34.045 & $25.337 * *$ & 1.444 & 0.121 & 2.423 & 13.646 \\
\hline $\begin{array}{l}\text { Entries (ignoring } \\
\text { blocks) }\end{array}$ & 202 & $41.284 * *$ & $89.737 * *$ & $6701.696^{* *}$ & $49.987 * *$ & $5.667 * *$ & $0.417 * *$ & $115.785 * *$ & $71.474 * *$ \\
\hline Varieties & 199 & $34.525^{* *}$ & $76.886^{* *}$ & $5841.54 * *$ & $36.327 * *$ & $4.011 * *$ & $0.387 * *$ & $100.857 * *$ & $64.347 * *$ \\
\hline Checks v/s varieties & 1 & $235.046^{* *}$ & 15.939 & $102745.195 * *$ & $715.723 * *$ & $258.749 * *$ & $2.114 * *$ & $299.9 * *$ & $180.619 * *$ \\
\hline Error & 18 & 2.67 & 12.766 & 24.29 & 5.834 & 1.341 & 0.117 & 1.774 & 19.972 \\
\hline
\end{tabular}

Table.3 Standard errors of mean and LSI for comparison of adjusted means

\begin{tabular}{|c|c|c|c|c|c|c|c|c|c|}
\hline STANDARD ERROR & FORMULLA & DF & DM & PH & NOP & $\mathbf{P L}$ & SPP & 100SW & SYP \\
\hline $\begin{array}{l}\text { Difference between two check } \\
\text { varieties }(\mathrm{Sc})\end{array}$ & $\sqrt{2} \mathrm{MSE} / \mathrm{R}$ & 0.731 & 1.598 & 2.204 & 1.080 & 0.518 & 0.153 & 0.596 & 1.998 \\
\hline $\begin{array}{l}\text { Difference between adjusted } \\
\text { means of two Test entries in the } \\
\text { same block }(\mathrm{Sb})\end{array}$ & $\sqrt{2 M S E}$ & 2.311 & 5.053 & 6.970 & 3.416 & 1.638 & 0.485 & 1.884 & 6.320 \\
\hline $\begin{array}{l}\text { Difference between adjusted } \\
\text { means of two test entries in } \\
\text { different blocks (Sv) }\end{array}$ & $\sqrt{2}(\mathrm{C}+1) \mathrm{MSE} / \mathrm{C}$ & 2.668 & 5.835 & 8.048 & 3.944 & 1.891 & 0.560 & 2.175 & 7.298 \\
\hline $\begin{array}{l}\text { Difference between adjusted test } \\
\text { entry and check mean }(\mathrm{Svc})\end{array}$ & $\begin{array}{l}\sqrt{ }\{(\mathrm{R}+1)(\mathrm{C}+1) \mathrm{MSE}\} / \\
\text { R.C }\end{array}$ & 1.933 & 4.227 & 5.831 & 2.858 & 1.370 & 0.406 & 1.576 & 5.288 \\
\hline Least Significant increase (LSI) & $\mathrm{t}_{\alpha} \cdot \mathrm{Svc}$ & 3.256 & 7.119 & 9.820 & 4.813 & 2.307 & 0.681 & 2.654 & 8.905 \\
\hline
\end{tabular}


Table.4 Eigen values (Latent roots) and variability of non-rotated values of Principal Components

\begin{tabular}{|c|c|c|c|}
\hline $\begin{array}{c}\text { Principal } \\
\text { Component }\end{array}$ & $\begin{array}{c}\text { Latent roots } \\
\text { (Eigen value) }\end{array}$ & $\begin{array}{c}\text { Proportion of variance } \\
\text { explained }\end{array}$ & $\begin{array}{c}\text { Cumulative } \\
\text { proportion }\end{array}$ \\
\hline PC1 & 2.375 & 0.297 & 0.297 \\
\hline PC 2 & 1.911 & 0.239 & 0.536 \\
\hline PC 3 & 1.222 & 0.153 & 0.688 \\
\hline PC 4 & 0.969 & 0.121 & 0.810 \\
\hline PC 5 & 0.629 & 0.079 & 0.888 \\
\hline PC 6 & 0.434 & 0.054 & 0.942 \\
\hline PC 7 & 0.340 & 0.042 & 0.985 \\
\hline PC 8 & 0.121 & 0.015 & 1.000 \\
\hline
\end{tabular}

Table.5 Non-rotated component loadings (values of principal component traits of common bean)

\begin{tabular}{|l|c|c|c|}
\hline Principal Component & PC1 & PC2 & PC3 \\
\hline Days to flowering & $\mathbf{0 . 5 0 1}$ & -0.186 & 0.055 \\
\hline Days to maturity & $\mathbf{0 . 4 8 2}$ & -0.083 & -0.086 \\
\hline Plant height & $\mathbf{0 . 4 8 3}$ & -0.135 & -0.151 \\
\hline Number of pods per plant & 0.008 & $\mathbf{- 0 . 5 9 2}$ & -0.240 \\
\hline Pod length & $\mathbf{- 0 . 4 3 3}$ & -0.227 & 0.022 \\
\hline Seeds per pod & -0.308 & -0.311 & -0.302 \\
\hline 100-seed weight & 0.011 & -0.100 & $\mathbf{0 . 8 7 0}$ \\
\hline Seed yield per plant & -0.016 & $\mathbf{- 0 . 6 5 7}$ & 0.246 \\
\hline Percent variation explained & $\mathbf{2 9 . 7 0}$ & $\mathbf{2 3 . 9 0}$ & $\mathbf{1 5 . 3 0}$ \\
\hline Cumulative percentage & $\mathbf{2 9 . 7 0}$ & $\mathbf{5 3 . 6 0}$ & $\mathbf{6 8 . 8 0}$ \\
\hline
\end{tabular}

Table.6 Correlation coefficients for eight quantitative traits in common bean

\begin{tabular}{|l|l|l|l|l|l|l|l|l|}
\hline Trait & $\begin{array}{l}\text { Days to } \\
\text { flowering }\end{array}$ & $\begin{array}{l}\text { Days to } \\
\text { maturity }\end{array}$ & $\begin{array}{l}\text { Plant } \\
\text { Height }\end{array}$ & $\begin{array}{l}\text { No. of } \\
\text { pods/plant }\end{array}$ & $\begin{array}{l}\text { Pod } \\
\text { length }\end{array}$ & $\begin{array}{l}\text { No. of } \\
\text { seeds/pod }\end{array}$ & $\begin{array}{l}\text { 100-seed } \\
\text { weight }\end{array}$ & $\begin{array}{l}\text { Seed } \\
\text { yield/plant }\end{array}$ \\
\hline $\begin{array}{l}\text { Days to } \\
\text { flowering }\end{array}$ & - & $0.631^{* *}$ & $0.475^{* *}$ & 0.075 & -0.256 & -0.144 & 0.093 & 0.154 \\
\hline Days to maturity & - & - & $0.396 * *$ & 0.026 & -0.248 & --0.155 & -0.032 & -0.004 \\
\hline Plant Height & - & - & - & 0.155 & $-0.431^{* *}$ & -0.161 & -0.059 & 0.080 \\
\hline No. of pods/plant & - & - & - & - & 0.128 & 0.147 & -0.180 & $0.679 * *$ \\
\hline Pod length & - & - & - & - & - & $0.448 * *$ & 0.064 & 0.170 \\
\hline No. Of seeds/pod & - & - & - & - & - & - & -0.156 & 0.262 \\
\hline 100-seed weight & - & - & - & - & - & - & - & $0.344 *$ \\
\hline Seed yield/plant & - & - & - & - & - & - & - & - \\
\hline
\end{tabular}


The Analysis of variance (Table 2) revealed significant mean sum of squares for all traits for different sources of variation. The Block effect (unadjusted) and the treatment effects (adjusted as well as unadjusted) were significant for all the traits. Similarly the effects due to checks and varieties were significant. However, the adjusted block effects were non-significant for all traits except pods per plant indicating homogeneity of evaluation blocks. Similarly, the mean square due to checks v/s varieties was significant for all the traits except days to maturity, indicating thereby that the test entries were significantly different from checks except for days to maturity. The standard errors of difference (Table 3 ) were computed for all traits for comparison of adjusted means of test entries in same block, test entries in different block, checks, test entries and checks. The least significant increase was computed to identify the test genotypes that significantly surpassed the best check. In the present study the number of genotypes that surpassed the best check was 19 (days to flowering), 37 (days to maturity), 88 (plant height), 2 (number of pods per plant), 1 (pod length), 5 (seeds per pod), 41 (100 seed weight) and 10 (seed yield per plant). Shalimar French Bean-1 was the best check for all traits except plant height (Arka Anoop) and 100-seed weight (Shalimar Rajmash-1).

\section{Principal component analysis}

The number of principal components (Table 4) was eight (equal to the number of traits observed). PCA concentrated on first three principal components (PC's) only as they accounted for the $68.8 \%$ of the total variation. The criteria followed for selecting the principal components to be included in further analysis was based on Eigen values of principal components (Kovacic, 1994). The fact that Eigen values are above unity indicates that the evaluated principal component weight is reliable (Mohammadi and Prassanna, 2003). In the present study only three principal components had Eigen values above unity and as such were considered. The latent roots ranged from 2.375 for first PC to 0.121 for the eighth PC. The first component explained $29.7 \%$ of variation followed by PC 2 (23.9\%) and PC 3 (15.3\%). The important traits in first PC were number of days to flowering (DF), number of days to maturity (DM) and plant height while as important trait in PC 3 was 100-seed weight. The first PC can be designated as component of maturity as it contains number of days to flowering and number of days to maturity while as third PC can be designated as component of productivity as it contains 100 -seed weight and seed yield per plant as important traits. Rana et al., (2015) also identified traits such as 100-seed weight, pod length, seeds per pod as important traits in four PC's that accounted for about $80.44 \%$ of variation. In a crop like common bean where breeding for a particular set of growing conditions holds promise, it is highly imperative to conserve and use the local populations, since in them the relationships among yield components are balanced and in harmony with the effects of the specific climatic and edaphic factors (Vasic et al., 2008). The principal component analysis (PCA), one of Multivariate Analysis methods elucidates among a set of the traits which ones are decisive in genotypic differentiation (Kovacic, 1994). PCA enables easier understanding of impacts and connections among different traits by identifying them and explaining their roles. This method is a powerful multiple method to apply evaluation yield component (Guertin and Bailey, 1982), identify biological relationships among traits (Acquaah et al., 1992), decrease associatedtraits to a few factors (Johnson and Wichern, 1996) and description of correlations among variables. Factor analysis has the potential of 
enhancing our knowledge of causal relationship of variables and can help to know the nature and sequences of traits to be selected for breeding program (Khameneh et al., 2012). The method has been used by many workers in elucidating getotypic differentiations in gene bank collections (Antunes et al., 1981; Acquaah et al., 1992; Brithers and Kelly, 1993; Vasic et al., 2008)

The knowledge of trait associations in common bean breeding material is essential for a variety of reasons: it enables us to perceive the diversity of breeding material and identify the trait through which a bean plant is able to grow successfully in a given ecological condition with optimum productivity and to avoid characters that have little or no breeding value. In combination with PCA; it enables us to narrow down to a very few traits that not only account for large amount of variation but have a breeding value correlated with seed yield. In the present study, number of days to flowering (DF) was significantly and positively correlated (Table $5)$ with the number of days to maturity (DM) and plant height. DM was also showed significant and positive correlation with plant height. Seed yield per plant was significantly and positively correlated with the number of pods per plant and 100-seed weight while as number of seeds per pod was positively correlated with pod length. The only significant negative correlation was between pod length and plant height. Similarly, positive but non-significant correlations were recorded between seed yield per plant and number of seeds per pod, pod length, DF as well as plant height. Among other traits, positive but non-significant correlation was recorded between number of seeds per pod and number of pods per plant; number of pods per plant and plant height; 100-seed weight and DF and 100-seed weight and pod length (Table 6). The basic criteria for using a trait or set of traits for indirect selection are high heritability of the trait and desirable correlations with yield. The compensation in different yield components may lead to variation in correlation pattern. Therefore there is a need to eliminate the nature and magnitude of inter-relationship between yield components. A large number of studies have reported positive correlation between seed yield and traits like 100-seed weight, number of pods per plant, seeds per pod as well as pod length (Coimbara et al., 1998; Dursun, 2007; Mudasir et al., 2012; Sofi et al., 2011 etc, Rana et al., 2015).

\section{References}

Acquaah, G, Adams, MW and Kelly, JD 1992. A factor analysis of plant variables associated with architecture and seed size in dry bean, Euphytica, 60,171-177.

Amanullah S and Muhammad A. 2011. Evaluation of common bean germplasm collected from the neglected pockets of northwest Pakistan at Kalam (swat). Pakistan Journal of Botany. 43, 213219.

Antunes, I, Teixeira, M, Zimmermann, MJO and Costa, JGC. 1981. Exploration of regional populations in common beans concepts and procedures adopted at the national research centre for rice and beans- cnpaf/Brazil. Annual Report BIC, 24-27.

Brithers, ME and Kelly, JD.1993). Interrelationship of plant architecture and yield components in the pinto bean ideotype, Crop Science 33, 1234 - 1238.

Federer, W. 1956. Augmented designs. Hawaiian Planter Recorder. 55, 191-208

Federer, W., Reynolds, M. and Crossa, J. 2001. Combining results from augmented designs over sites. Agron J. 93, 389-395 
Guertin WH and Bailey JP 1982. Introduction to modern factor analysis. Edwards Brothers (ed) Inc Michigan USA.

Johnson RA and Wichern DW. 1996. Applied multivariate statistical analysis. Sterling Book House New Delhi.

Kovacic, Z. 1994. Multivarijaciona analiza. Univerzitet u Beogradu, Ekonomski fakultet, 282str.

Khameneh, MM, Bahraminejad, S, Sadeghi, F, Honarmand, J and Maniee, M. 2012. Path analysis and multivariate factorial analyses for determining interrelationships between grain yield and related characters in maize hybrids. African Journal of Agricultural Research 7, 6437-6446

Mohammadi, SA and Prasanna, BM. 2003. Analysis of Genetic Diversity in Crop Plants-Salient Statistical Tools and Considerations. Crop Science 43, 12351248

Nadrajan, N. and Chaturvedi, S. 2010. Genetic options for productivity enhancements of major pulsesretrospect, issues and strategies. J. Food legumes. 23: 1-8.

Razvi, SM. Sofi, PA, Khan, MN, Sofi, NR and Dar, ZA. 2012. Genetic diversity, variability and character association in local common bean (Phaseolus vulgaris L.) germplasm of Kashmir. Electronic Journal of Plant Breeding. 3, 883-891

Rana, J C., Shatma, T R. Tyagi, R K., Chahota, N K, Gautam, P K., Sharma, P N., Singh, M. and Ojha, S N. 2015. Characterisation of 4274 accessions of common bean (Phaseolus vulgaris L.) germplasm conserved in the Indian gene bank for phenological, morphological and agricultural traits. Euphytica.205, 441-457

Salehi, M, Tajik, M and Ebadi, A. 2008. The relationship between different traits I common bean using multivariate statistical methods. American-Eurasian Journal of Agriculture \& Environment 3, 806-809

Vasic M., Gvozdanovic-Varga, J and Takac, A 2001. Selekcija pasulja (Dry bean breeding). Savremena poljoprivredaContemporary Agriculture, Novi Sad, (1-2), 237-245.

Vasic, M, Varga, J and Cervenski, J. 2008. Divergence in dry bean collection by principal component analysis. Genetika. 40, 23-30

Vasic, M. 1982. Divergence in Dry Bean Collection 29 Conti, L. 1982. Bean germplasm evaluation from the collection at Minoprio (Como, Italy) in view of a breeding program for the improvement of the protein content of the seed. Genetika Agraria (3-4), 375392.

Vasic, M. 1986). Osobine zrna nekih domacih populacija pasulja. Jug. Simp. "Intenzivna proizvodnja povrca za zdravu ishranu", Split, 119-125.

Singh SP. 2001. Broadening the genetic base of common bean cultivars. Crop Science. 41, 1659-1675.

Sofi PA, Zargar MY, Debouck D and Graner A. 2011. Evaluation of common bean genotypes under temperate conditions of Kashmir valley. J. Phytology. 3, 4752.

\section{How to cite this article:}

Iram Saba, Parvaze A. Sofi, N.A. Zeerak, R.R. Mir and Musharib Gull. 2017. Using Augmented Design for Evaluation of Common Bean (Phaseolus vulgaris L.) Germplasm. Int.J.Curr.Microbiol.App.Sci. 6(7): 246-254. doi: https://doi.org/10.20546/ijcmas.2017.607.029 